\title{
KAJIAN KEPATUHAN WAJIB PAJAK PRIBADI DITINJAU DARI PEMAHAMAN PERATURAN PERPAJAKAN DAN SANKSI PERPAJAKAN
}

\author{
Sukma Ayu Fardha Jihin, Wiwit Apit Sulistyowati, Salta* \\ Universitas Swadaya Gunung Jati Cirebon \\ *e-mail: wiwit.apit@gmail.com
}

DiPublikasi: 01/01/2021

http://dx.doi.org/10.22225/kr.11.2.1154.190-196

\begin{abstract}
Each taxpayer must comply with the general provisions of taxation that already exist, but the taxpayer cannot be separated from his negligence in fulfilling tax obligations, for that tax compliance is an attempt by a taxpayer in fulfilling and implementing the tax liability is in accordance with the rules in the tax laws. Therefore this study aims to analyze and determine the effect of understanding tax regulations and tax sanctions on the compliance of individual taxpayers who are registered at KPP Pratama Cirebon Satu. The sample used in this study were 100 personal taxpayers. This type of research is basic research. The primary data collection method used is a survey method using questionnaire media. Data analysis method used is multiple regression analysis using SPSS software version 25. The results of this study indicate that the understanding of tax regulations and tax penalties affect the personal taxpayers compliance registered at KPP Pratama Cirebon Satu.

Keywords: Understanding of Taxation Regulations, Tax Sanctions, Taxpayer Compliance

Setiap wajib pajak harus mematuhi ketentuan umum perpajakan yang telah ada, namun wajib pajak juga tidak terlepas dari kelalaiannya dalam memenuhi kewajiban perpajakan, untuk itu kepatuhan wajib pajak adalah upaya seorang wajib pajak dalam memenuhi dan melaksanakan kewajiban pajaknya sesuai dengan aturan yang berlaku dalam undang-undang perpajakan. Oleh karena itu penelitian ini bertujuan untuk menganalisis dan mengetahui pengaruh pemahaman peraturan perpajakan dan sanksi perpajakan terhadap kepatuhan wajib pajak orang pribadi yang terdaftar di KPP Pratama Cirebon Satu. Sampel yang digunakan dalam penelitian ini sebanyak 100 wajib pajak pribadi. Jenis penelitian ini adalah penelitian dasar. Metode pengumpulan data primer yang digunakan adalah metode survei dengan menggunakan media kuesioner. Metode analisis data yang dipakai adalah analisis regresi berganda dengan menggunakan software SPSS versi 25. Hasil penelitian ini menunjukan bahwa pemahaman peraturan perpajakan dan sanksi perpajakan berpengaruh terhadap kepatuhan wajib pajak orang pribadi yang terdaftar di KPP Pratama Cirebon Satu.
\end{abstract}

Kata Kunci : Pemahaman Peraturan Perpajakan, Sanksi Perpajakan, Kepatuhan Wajib Pajak

\section{PENDAHULUAN}

Pajak menurut Undang-undang merupakan kontribusi wajib kepada negara yang terutang oleh orang pribadi atau badan yang bersifat memaksa, tidak mendapatkan imbalan secara langsung dan digunakan untuk keperluan negara bagi sebesarbesarnya kemakmuran rakyat. Tabel 1 berikut menunjukkan bahwa sumber terbesar penerimaan anggaran pendapatan dan belanja Negara Indonesia yaitu dari penerimaan pajak.
Tabel 1

Penerimaan APBN Tahun 2017-2019 (dalam Triliun Rupiah) Jumlah

\begin{tabular}{|c|c|c|c|}
\hline \multirow{3}{*}{$\begin{array}{r}\text { Tahu } \\
\text { n Anggaran }\end{array}$} & \multicolumn{2}{|c|}{ (dalam triliun) } & \multirow{3}{*}{$\begin{array}{r}\text { Prese } \\
\text { ntase Pajak }\end{array}$} \\
\hline & \multicolumn{2}{|c|}{$\mathrm{A}$} & \\
\hline & PBN & ajak & \\
\hline \multirow[t]{2}{*}{2017} & 1 & 1 & \\
\hline & $.283,6$ & $.151,5$ & $89,74 \%$ \\
\hline \multirow[t]{2}{*}{2018} & 1 & 1 & 92,4 \\
\hline & $.424,0$ & $.315,9$ & $\%$ \\
\hline \multirow[t]{2}{*}{2019} & 1 & 1 & 84,6 \\
\hline & $.557,6$ & $.332,1$ & $\%$ \\
\hline
\end{tabular}

Tabel 1 menjelaskan bahwa pertumbuhan tahunan penerimaan pajak pada tahun 2017 sebesar $89.74 \%$. pada tahun 2018 penerimaan pajak 
mengalami kenaikan sebesar 92,4\%, tetapi pada tahun 2019 penerimaan pajak mengalami penurunan dan hanya mendapat presentase sebesar $84,6 \%$ hal ini terjadi karena banyak faktor yang dianggap sebagai penyebab turunnya penerimaan pajak pada tahun 2019 ini yaitu, adanya penurunan ekspor dan impor dibandingkan tahun lalu yang cukup tinggi dan faktor global yang membuat penerimaan pajak presentasenya menurun (https://katadata.co.id).

Undang-Undang Ketentuan Umum dan Tata Cara Perpajakan No. 16 Tahun 2009 menjelaskan bahwa semua Wajib Pajak yang telah memenuhi persyaratan subjektif dan objektif yang sesuai dengan ketentuan peraturan perundang-undangan perpajakan harus memenuhi kewajiban perpajakannya. Sistem pemungutan pajak saat ini yang berlaku di Indonesia yaitu self assesment system merupakan sistem perpajakan yang mana seorang wajib pajak harus mendaftarkan diri pada kantor Direktorat Jendral Pajak untuk menghitung, membayar dan melaporkan pajak yang terutangnya sendiri.

Direktorat Jenderal Pajak menyatakan bahwa kepatuhan perpajakan adalah tingkat di mana wajib pajak mematuhi undang-undang dan administrasi perpajakan tanpa perlunya kegiatan penegakan hukum. Tetapi permasalahan yang sering terjadi yakni banyaknya masyarakat yang tidak dapat memenuhi kewajiban perpajakannya, sehingga tingkat kepatuhan wajib pajak yang terdaftar untuk memenuhi kewajiban perpajakannya di Indonesia masih rendah.

Fenomena mengenai kepatuhan wajib pajak dijelaskan dalam tabel 2 dibawah ini yang mana tingkat kepatuhan wajib pajak secara global selama tiga tahun terakhir yaitu tahun 2017 sampai dengan 2019 di Indonesia dalam memenuhi kewajiban pajaknya masih tergolong rendah, karena jumlah wajib pajak yang melapor surat pemberitahuan tahunan (SPT) selalu dibawah target jumlah wajib pajak yang terdaftar untuk melapor SPT.

\section{Tabel 2}

Tingkat Kepatuhan Wajib Pajak di Indonesia tahun 2017-2019

\begin{tabular}{|c|c|c|c|c|c|}
\hline \multirow{3}{*}{$\begin{array}{c}\text { Tahu } \\
\mathrm{n}\end{array}$} & \multirow{3}{*}{$\begin{array}{c}\text { Jumlah } \\
\text { Wajib Pajak } \\
\text { yang } \\
\text { Terdaftar }\end{array}$} & \multirow{2}{*}{\multicolumn{2}{|c|}{$\begin{array}{c}\text { Jumlah Wajib Pajak yang } \\
\text { Melapor SPT }\end{array}$}} & \multirow{3}{*}{$\begin{array}{c}\text { Target } \\
\text { Pemerintah } \\
\text { dalam } \\
\text { Pelaporan } \\
\text { SPT }\end{array}$} & \multirow{3}{*}{$\begin{array}{l}\text { Tingka } \\
\text { Kepatu } \\
\text { han (\% }\end{array}$} \\
\hline & & & & & \\
\hline & & WP Pribadi & $\begin{array}{c}\text { WP } \\
\text { Badan }\end{array}$ & & \\
\hline 2017 & 36.031 .972 & 9.082 .241 & 770.000 & 12.450 .000 & $58,98 \%$ \\
\hline 2018 & 38.651 .881 & 11.690 .000 & 850.000 & 14.000 .000 & $71 \%$ \\
\hline 2019 & 42.000 .000 & 12.400 .000 & 961.660 & 15.580 .500 & $73 \%$ \\
\hline
\end{tabular}

Tabel 2 menjelaskan bahwa tingkat kepatuhan wajib pajak dari tahun ke tahun meningkat tetapi wajib pajak yang melapor SPT tidak pernah tercapai hingga $100 \%$ dari target, hal ini bisa terjadi karena beberapa masalah yaitu minimnya pemahaman wajib pajak, kurangnya sosialisasi perpajakan dari aparat pajak, dan tidak memahami tentang tata cara perpajakan yang baik dan benar, serta sanksi sebesar $2 \%$ untuk keterlambatan menyampaikan SPT masih dinilai kurang tegas untuk meningkatkan tingkat kepatuhan wajib pajak (https://tirto.id).

\section{Tabel 3}

Tingkat Kepatuhan Wajib Pajak di KPP Pratama Cirebon Satu tahun 2017-2018

\begin{tabular}{cccc}
\hline ahun & $\begin{array}{c}\text { Jum } \\
\text { lah Wajib } \\
\text { Pajak } \\
\text { Pribadi }\end{array}$ & $\begin{array}{c}\text { Wa } \\
\text { jib Pajak } \\
\text { yang } \\
\text { Lapor SPT }\end{array}$ & $\begin{array}{c}\text { Prese } \\
\text { ntase } \\
\text { Kepatuhan }\end{array}$ \\
\hline${ }^{\prime}$ & 150. & 25. & $17 \%$ \\
\hline & 816 & 601 & $17 \%$ \\
\hline & 156. & 26. & \\
\hline
\end{tabular}

Sumber: KPP Pratama Cirebon Satu

Tabel 3 menjelaskan bahwa tingkat kepatuhan wajib pajak di KPP Pratama Cirebon Satu hanya 17\% pada tahun 2017 dan 2018 masih belum sepenuhnya terpenuhi karena banyak wajib pajak yang tidak lapor SPT, hal ini dikarenakan menurut Jendral Pajak Kementrian Keuangan, Ken Dwijugiasteadi menjelaskan beberapa faktor yang memicu masyarakat masih tidak patuh dalam membayar pajak, yaitu: sebagian masyarakat tidak percaya dengan undang-undang di bidang perpajakan, pengisian Surat Pemberitahuan (SPT) Tahunan Pajak dan Penghasilan (PPh) dinilai sulit, serta membayar pajak belum menjadi budaya masyarakat Indonesia (https://m.liputan6.com).

Beberapa factor yang mempengaruhi kepatuhan wajib pajak adalah pemahaman peraturan perpajakan dan sanksi perpajakan. Wajib pajak yang memahami peraturan yang telah ada adalah sebagian proses dari pemahaman peraturan perpajakan. Terdapat penelitian sebelumnya membahas tentang kepatuhan wajib pajak, seperti yang dilakukan oleh, (Priambodo \& Yushita, 2017), (Efriyenty, 2017), (Kusuma, 2017), (Bahri et al., 2018), dan (As'ari, 2018) yang meneliti tentang pemahaman peraturan perpajakan menyatakan bahwa pemahaman peraturan perpajakan berpengaruh terhadap kepatuhan wajib pajak. 
Semakin tinggi pemahaman peraturan perpajakan setiap wajib pajak maka akan tinggi pula kepatuhan wajib pajaknya, hal ini karena apabila wajib pajak memahami proses perpajakan untuk memenuhi kewajiban perpajakannya maka akan meningkatkan kepatuhan wajib pajak.

Tetapi berbeda dengan penelitian yang dilakukan oleh (Saragih \& S, 2017) yang menyatakan bahwa pemahaman peraturan perpajakan tidak berpengaruh terhadap kepatuhan wajib pajak, hal ini karena terlihat dari tanggapan responden wajib pajak ukm seberang ulu, mengenai pemahaman peraturan pajak, wajib pajak yang diteliti cenderung tidak menerima resiko dan menyebabkan preferensi resiko tidak berpengaruh antara variabel pemahaman peraturan perpajakan dan kepatuhan wajib pajak.

Factor lain yang mempengaruhi kepatuhan wajib pajak adalah sanksi perpajakan yang mana sebuah aturan harus dipatuhi karena adanya sanksi perpajakan itu agar wajib pajak tidak melanggar undang-undang perpajakan. Penelitian lainnya dilakukan oleh (Ngadiman \& Huslin, 2016), (Ariesta \& Latifah, 2017), (Alfiyah \& Latifah, 2017), (Tene et al., 2017), (I. P. E. Adiputra \& Wirama, 2017), (Brata et al., 2017), (Saragih \& S, 2017), dan (Agustini \& Widhiyani, 2019) yang meneliti tentang sanksi perpajakan menyatakan bahwa sanksi perpajakan berpengaruh terhadap kepatuhan wajib pajak. Semakin tinggi sanksi perpajakan maka akan tinggi pula kepatuhan wajib pajaknya, hal ini karena jika sanksi perpajakan diterapkan secara tegas kepada wajib pajak maka akan membuat tingkat kepatuhan wajib pajaknyapun tinggi.

Tetapi berbeda dengan penelitian yang dilakukan oleh (Bahri et al., 2018) dan (Putri \& Agustin, 2018) yang menyatakan bahwa sanksi perpajakan tidak berpengaruh terhadap kepatuhan wajib pajak, karena pelanggaran norma perpajakan akan terus terjadi apabila sanksi perpajakan ditetapkan ataupun dibuat tanpa adanya sosialisasi yang baik dan tidak adanya tindakan yang nyata atas penerapan sanksi akan membuat wajib pajak menganggap remeh atas sanksi perpajakan yang ada.

Berdasarkan fenomena belum tercapainya target penerimaan pajak dan hasil penelitian terdahulu yang tidak konsisten, maka penelitan ini bertujuan untuk menguji pengaruh pemahaman peraturan perpajakan dan sanksi pajak terhadap kepatuhan wajib pajak.

\section{TINJAUAN PUSTAKA}

\section{Teori Atribusi}

Menurut (Robbins \& Jugde, 2017) teori atribusi adalah teori yang menjelaskan bahwa ketika individu mengamati perilaku seorang, individu tersebut berupaya untuk menentukan apakah perilaku tersebut disebabkan secara internal atau eksternal. Perilaku yang disebabkan secara internal merupakan perilaku yang diyakini berada di bawah kendali pribadi seorang individu, dengan kata lain tidak terpengaruh oleh hal lain. Perilaku yang disebabkan secara eksternal merupakan perilaku yang dianggap sebagai akibat dari sebab-sebab luar yaitu individu tersebut dianggap telah dipaksa berperilaku demikian oleh situasi.

Teori atribusi relevan untuk menjelaskan penelitian ini, sebab perilaku seseorang wajib pajak dalam memenuhi kepatuhan perpajakannya ditentukan oleh suatu keadaan, baik dari faktor internal adalah pemahaman peraturan, merupakan dasar yang harus dimiliki agar wajib pajak dapat patuh untuk membayar pajak dan factor eksternal yang dapat mempengaruhi kepatuhan wajib pajak adalah sanksi perpajakan, hal itu disebabkan karena perilaku tersebut dipengaruhi oleh tuntutan situasi. Faktor internal dan eksternal tersebut dapat mempengaruhi wajib pajak dalam mengambil keputusan untuk patuh atau tidak patuh dalam membayar pajak.

\section{Kepatuhan Wajib Pajak}

Setiap wajib pajak harus mematuhi ketentuan umum perpajakan yang telah ada, namun wajib pajak juga tidak terlepas dari kelalaiannya dalam memenuhi kewajiban perpajakan, untuk itu diharapkan setiap wajib pajak mampu untuk memenuhi kewajiban perpajakannya. Wajib pajak yang dapat dikatakan baik apabila wajib pajak tersebut patuh mengenai ketentuan peraturan yang telah ada (Pohan, 2016). Untuk mencapai kepatuhan wajib pajak diperlukan penciptaan iklim perpajakan (yang bertujuan untuk menaikan kepatuhan wajib pajak) yaitu:

1. Wajib pajak paham dan berusaha memahami UU Perpajakan

2. Mengisi formulir pajak dengan benar

3. Menghitung pajak dengan jumlah yang benar

4. Membayar pajak tepat pada waktunya

"kepatuhan wajib pajak yaitu seluruh kewajiban 
perpajakan ialah suatu hal yang harus dipenuhi oleh wajib pajak serta menjadi hak setiap wajib wajib pajak untuk melaksanakan perpajakannya."

Berdasarkan Ditjen Pajak bahwa kriteria kepatuhan wajib pajak adalah:

1. Tepat waktu dalam menyampaikan SPT

2. Tidak mempunyai tunggakan pajak untuk semua jenis pajak, kecuali telah memperoleh izin untuk mengangsur atau menunda pembayaran pajak

3. Laporan keuangan diaudit oleh Akuntan Publik atau lembaga pengawasan keuangan pemerintah dengan pendapat wajar tanpa pengecualian selama 3 (tiga) tahun berturutturut, dan

4. Tidak pernah dipidana karena melakukan tindak pidana di bidang perpajakan berdasarkan putusan pengadilan yang telah mempunyai kekuatan hukum tetap dalam jangka waktu 5 (lima) tahun terakhir.

\section{Pemahaman Peraturan Perpajakan}

Pemahaman peraturan perpajakan merupakan suatu sikap dan sifat yang ditunjukan oleh wajib pajak pada saat memenuhi kewajiban perpajakannya. Pemahaman Peraturan ini mengacu pada Peraturan Undang-Undang Republik Indonesia Nomor 6 Tahun 1983 tentang Ketentuan Umum dan Tata Cara Perpajakan Sebagaimana Telah Beberapa kali Diubah Terakhir dengan Undang-Undang Republik Indonesia Nomor 16 Tahun 2009 yang menjelaskan bahwa semua wajib pajak yang tekah memenuhi persyaratan subjektif dan objektif yang sesuai dengan ketentuan perundang-undangan perpajakan harus memenuhi kewajiban perpajakannya. Beberapa definisi lain mengenai pemahaman mengenai perpajakan juga telah diungkapkan (Nirawan, 2013), (H. Adiputra, 2014), bahwa pemahaman peraturan perpajakan adalah proses seorang wajib pajak akan memahami tentang peraturan perpajakan dan menerapkannya untuk melakukan kegiatan perpajakan.

Menurut (As'ari, 2018) terdapat tiga indikator yang dapat menjelaskan tentang pemahaman peraturan perpajakan diantaranya yaitu:

1. Memahami mengenai ketentuan umum dan tata cara perpajakan.

2. Memahami mengenai fungsi perpajakan.

3. Kepatuhan dalam menghitung dan membayar pajak dengan benar.

\section{Sanksi Perpajakan}

Menurut undang-undang sanksi perpajakan dapat berupa sanksi administrasi dan sanksi pidana yang dijelaskan sebagai berikut:

1. Sanksi Administrasi

Sanksi administrasi bersifat denda dan bunga, apabila surat pemberitahuan tidak disampaikan dalam jangka waktu yang telah ditetapkan maka dikenai sanksi sebesar Rp 500.000 untuk Surat Pemberitahuan Masa Pajak Pertambahan Nilai, Rp 100.000 untuk Surat Pemberitahuan Masa lainnya, dan sebesar $\mathrm{Rp} 1.000 .000$ untuk Surat Pemberitahuan Tahunan Pajak Penghasilan Wajib Pajak Badan serta sebesar 100.000 untuk Surat Pemberitahuan Tahunan Pajak Orang Pribadi, dan sanksi administrasi berupa bunga $2 \%$ per bulan atas jumlah pajak yang kurang bayar, dihitung sejak jatuh tempo pembayaran sampai dengan tanggal pembayaran dan bagian dari bulan dihitung penuh satu bulan. Sanksi administrasi sebagaimana diatur dalam pasal 7 ayat 1 adalah untuk kepentingan tertib administrasi perpajakan dan meningkatkan kepatuhan wajib pajak dalam memenuhi kewajiban menyampaikan Surat Pemberitahuan.

\section{Sanksi Pidana}

Sanksi pidana merupakan yang hasil akhir dari hukum yang diatur dalam undang-undang digunakan agar peraturan perpajakan dapat dipatuhi. Menurut perpajakan adalah salah satu upaya pemerintah memberikan ancaman berupa sanksi kepada wajib pajak yang tidak taat dengan kewajiban perpajakannya dengan sanksi administrasi dan sanksi pidana.

Menurut (As'ari, 2018) terdapat tiga indikator yang dapat menjelaskan tentang sanksi perpajakan diantaranya yaitu:

1. Sanksi perpajakan yang dikenakan bagi pelanggar aturan pajak cukup berat.

2. Penggenaan sanksi pajak yang cukup berat merupakan salah satu saran untuk mendidik wajib pajak.

3. Sanksi pajak harus dikenakan kepada pelanggarnya tanpa toleransi.

\section{Hasil Penelitian Sebelumnya}

Ngadiman dan Daniel Huslin, 2015 Pengaruh Sunset Policy, Tax Amnesty, dan Sanksi pajak terhadap Kepatuhan Wajib Pajak (Studi Empiris di Kantor Pelayanan Pajak Pratama Jakarta Kembangan) dengan hasil penelitian bahwa Suncet Policy tidak berpenoaruh terhadap 
kepatuhan wajib pajak serta Tax Amnesty dan Sanksi Pajak berpengaruh terhadap Kepatuhan Wajib Pajak.

Putut Priambodo, 2017 Pengaruh Pemahaman Peraturan Perpajakan, Sanksi Perpajakan dan Kesadaran Wajib Pajak terhadap Kepatuhan Wajib Pajak Orang Pribadi di Kantor Pelayanan Pajak Pratama Kabupaten Purwerejo Tahun 2017 dengan hasil penelitian bahwa Sanksi Perpajakan dan Kesadaran Wajib Pajak berpengaruh terhadap Kepatuhan Wajib Pajak.

Kartika Candra Kusuma, 2017 Pengaruh Kualitas Pelayanan Pajak, Pemahaman Peraturan Perpajakan Serta Sanksi Perpajakan Terhadap Kepatuhan WPOP dengan hasil penelitian bahwa Kualitas pelayanan, Pemahaman Peraturan Perpajakan dan Sanksi Perpajakan berpengaruh terhadap Kepatuhan Wajib Pajak

Januar Dio Brata, Isna Yuningsih dan Agus Iwan Kusuma, 2017 Pengaruh Kesadaran Wajib Pajak, Pelayanan Fiskus, dan Sanksi Pajak terhadap Kepatuhan Wajib Pajak Orang Pribadi yang Melakukan Kegiatan Usaha dan Pekerjaan Bebas di Kota Samarinda dengan hasil penelitian Keasadaran Wajib Pajak dan Sanksi Pajak berpengaruh terhadap Kepatuhan Wajib pajak serta Pelayanan Fiskus tidak berpengaruh terhadap kepatuhan Wajib Pajak.

Putu Eka Adiputra dan Dewa Gede Wirama, 2017 Pengaruh Kualitas Pelayanan, Sanksi Perpajakan dan Kesadaran Wajib Pajak terhadap Kepatuhan Wajib Pajak dengan hasil penelitian bahwa Kualitas Pelayanan, Sanksi Perpajakan dan Kesadaran Wajib Pajak berpengaruh terhadap Kepatuhan Wajib Pajak

Johanes Herbert Tene, Jullie J. Sondakh dan Jessy D.L. Warongan, 2017 Pengaruh Pemahaman Wajib Pajak, Kesadaran Pajak, Sanksi Perpajakan, dan Pelayanan Fiskus terhadap Kepatuhan Wajib Pajak (Studi Empiris pada wajib pajak orang pribadi yang terdaftar di KPP Pratama Manado) dengan hasil penelitian bahwa Pemahaman Wajib Pajak, Kesadaran Wajib Pajak, Sanksi Perpajakan berpengaruh terhadap Kepatuhan Wajib Pajak, serta Pelayan fiskus tidak berpengaruh terhadap Kepatuhan
Wajib Pajak.

Dian Efryenty, 2017 Pengaruh Kualitas Pelayanan Pajak, Pemahaman Peraturan Perpajakan serta Sanksi Perpajakan terhadap kepatuhan Wajib Pajak Orang Pribadi yang Terdaftar di kantor Pelayanan Pajak Pratama Kota Batam dengan hasil penelitian bahwa Kualitas Pelayanan Pajak, Pemahaman Peraturan Perpajakan, dan Sanksi Perpajakan berpengaruh terhadap Kepatuhan Wajib Pajak

Ristra Putri Ariesta dan Lyna Latifah, 2017 Pengaruh Kesadaran Wajib Pajak, Sanksi Perpajakan, Sistem Administrasi Perpajakan Modern, Pengetahuan Korupsi, dan Tax Amnesty Terhadap Kepatuhan Wajib Pajak di KPP Pratama Semarang dengan hasil penelitian bahwa Kesadaran Wajib Pajak, Sanksi Perpajakan, Sistem Administrasi, Pengetahuan Korupsi, dan Tax Amnesty berpengaruh terhadap Kepatuhan Wajib Pajak

Nur Alfiyah dan Sri Wahjuni Latifah, 2017 Pengaruh Pelaksanaan Kebijakan Sunset Policy, Tax Amnesty, Dan Sanksi Pajak Terhadap Kepatuhan Wajib Pajak Orang Pribadi dengan hasil penelitian bahwa Pelaksanaaan Kebijakan Sunset Policy, Tax Amnesty, dan Sanksi Perpajakan berpengaruh terhadap Kepatuhan Wajib Pajak

Fitriani Saragih dan Dessy S, 2017 Pengaruh Kesadaran Wajib Pajak, Pemahaman Peraturan Perpajakan serta Sanksi Perpajakan Terhadap Kepatuhan Wajib Pajak Orang Pribadi (Pada KPP Pratama Medan Kota) dengan hasil penelitian bahwa Kesadaran Wajib Pajak dan Sanksi Perpajakan berpengaruh terhadap Kepatuhan Wajib Pajak serta Pemahaman Peraturan Perpajakan tidak berpengaruh terhadap Kepatuhan Wajib Pajak

Nur Ghalina As'ari, 2018 Pengaruh Pemahaman Peraturan Perpajakan, Kualitas Pelayanan, Kesadaran Wajib Pajak dan Sanski Perpajakan terhadap Kepatuhan Wajib Pajak (Studi Empiris pada Wajib Pajak Orang Pribadi Kecamatan Rongkop) dengan hasil penelitian bahwa Pemahaman Peraturan Perpajakan, Kualitas Pelayanan, dan Sanksi Perpajakan berpengaruh 
terhaadap Kepatuhan Wajib Pajak, serta Kesadaran Wajib Pajak tidak berpengaruh terhadap Kepatuhan Wajib Pajak

Saiful Bahri, Yossi Diantimala, dan Shabri Abd. Majid, 2018 Pengaruh Kualitas Pelayanan, Pemahaman Peraturan Perpajakan serta Sanksi Perpajakan terhadap Kepatuhan Wajib Pajak (Pada Kantor Pajak Pratama Kota Banda Aceh) dengan hasil penelitian Kualitas Pelayanan dan Sanksi Perpajakan tidak berpengaruh terhadap Kepatuhan Wajib Pajak serta Pemahaman Peraturan Perpajakan berpengaruh terhadap Kepatuhan Wajib Pajak

Narti Eka Putri dan Dessy Agustin, 2018 Pengaruh Pengertahuan Perpajakan dan Sanksi Perpajakan terhadap Kepatuhan Wajib Pajak Pribadi (Studi Kasus: KPP Pratama Kebayoran Lama Kota Jakarta Selatan) dengan hasil penelitian Pengetahuan Perpajakan berpengaruh terhadap Kepatuhan Wajib Pajak serta Sanksi Perpajakan tidak berpengaruh terhadap Kepatuhan Wajib Pajak

Komang Dwi Agustini dan Ni Luh Sari Widhiyani, 2019 Pengaruh Penerapan E-Filing, Sosialisasi Perpajakan, Sanksi Perpajakan Terhadap Kepatuhan Wajib Pajak Orang Pribadi dengan hasil penelitian Penerapan EFilling, Sosialisasi Perpajakan, dan Sanksi Perpajakan berpengaruh terhadap Kepatuhan Wajib Pajak

Pengaruh Pemahaman Peraturan Pajak, Sanksi Perpajakan, Pemeriksaan Pajak terhadap Kepatuhan Wajib Pajak Orang Pribadi dengan hasil penelitian bahwa Pemahaman Peraturan Perpajakan tidak berpengaruh terhadap Kepatuhan Wajib Pajak serta Sanksi Perpajakan dan Pemeriksaan Pajak berpengaruh terhadap Kepatuhan Wajib Pajak

\section{Kerangka Pemikiran dan Hipotesis}

Pemahaman Peraturan Perpajakan terhadap Kepatuhan Wajib Pajak Orang Pribadi

Menurut (Robbins \& Jugde, 2017) bahwa teori atribusi merupakan hubungan sebab-akibat yang disebabkan oleh perilaku internal seorang wajib pajak, dalam hal ini pemahaman peraturan perpajakan artinya dasar yang harus dimiliki agar wajib pajak dapat patuh untuk membayar pajak.

Pemahaman peraturan perpajakan adalah seorang wajib pajak yang memahami dan mengerti akan peraturan-peraturan dalam hal perpajakan. Apabila wajib pajak memahami peraturan-peraturan tersebut maka akan mempermudah wajib pajak saat melakukan kegiatan perpajakannya dan menerapkan apa yang sudah dipahami. Pemahaman peraturan perpajakan yang baik dan benar oleh wajib pajak yaitu seperti memiliki pengetahuan mengenai ketentuan umum dan tata cara perpajakan, pengetahuan mengenai fungsi perpajakan, dan kepatuhan dalam menghitung dan membayar pajak dengan benar. Oleh karena itu wajib pajak yang memahami peraturan perpajakan yang baik dan benar akan meningkatkan tingkat kepatuhan wajib pajaknya.

Argumen tersebut didukung oleh penelitian (Efriyenty, 2017), bahwa ketika seorang wajib pajak memahami ketentuan perpajakan dan norma perpajakan maka dapat pula memahami peraturan perpajakannya. Sehingga semakin tinggi pemahaman peraturan perpajakan setiap wajib pajak maka akan tinggi pula kepatuhan wajib pajaknya. Hasil penelitian ini sejalan dengan (Priambodo \& Yushita, 2017), (Kusuma, 2017), (Bahri et al., 2018), dan (As'ari, 2018).

Berdasarkan penjelasan tersebut, maka rumusan hipotesis penelitian ini adalah:

H1: Pemahaman Peraturan Perpajakan berpengaruh terhadap Kepatuhan Wajib Pajak Orang Pribadi

Sanksi Perpajakan terhadap Kepatuhan Wajib Pajak Orang Pribadi

Menurut (Robbins \& Jugde, 2017) bahwa teori atribusi merupakan hubungan sebab-akibat yang disebabkan oleh perilaku eksternal seorang wajib pajak. Dalam hal ini sanksi perpajakan dapat mempengaruhi kepatuhan wajib pajak hal itu disebabkan karena perilaku tersebut dipengaruhi oleh tuntutan situasi.

Sanksi perpajakan adalah sebuah kebijakan yang dibuat oleh pemerintah untuk menindak wajib pajak yang melakukan pelanggaran dalam perpajakan dan sanksi juga diperlukan agar peraturan perpajakan tidak dilanggar. Wajib pajak yang mengetahui sanksi perpajakan bahwa sanksi perpajakan yang dikenakan bagi pelanggar aturan itu cukup berat, pengenaan sanksi pajak yang cukup berat merupakan salah satu saran untuk mendidik wajib pajak, dan sanksi pajak harus dikenakan kepada pelanggarnya tanpa toleransi. Apabila wajib pajak 
patuh dalam melakukan kewajiban perpajakannya maka sanksi tidak akan dikenakan dan akan meningkatkan tingkat kepatuhan wajib pajaknya.

Argumen tersebut didukung dengan penelitian (I. P. E. Adiputra \& Wirama, 2017) menyatakan bahwa sanksi perpajakan yang diterapkan secara tegas pada wajib pajak akan meningkatkan kepatuhan wajib pajak. Secara logika bila wajib pajak melanggar peraturan perpajakan maka akan diberikan sanksi yang berlaku, apabila semakin tinggi sanksi perpajakan yang diberlakukan maka semakin tinggi kepatuhan wajib pajaknya. Hasil penelitian ini sejalan dengan penelitian (Ngadiman \& Huslin, 2016), (Ariesta \& Latifah, 2017), (Alfiyah \& Latifah, 2017), (Tene et al., 2017), (Brata et al., 2017), dan (Agustini \& Widhiyani, 2019).

Berdasarkan penjelasan tersebut, maka rumusan hipotesis penelitian ini adalah:

H2: Sanksi Perpajakan berpengaruh terhadap Kepatuhan Wajib Pajak

Berdasarkan uraian di atas, maka kerangka pemikiran dapat digambarkan sebagai berikut:

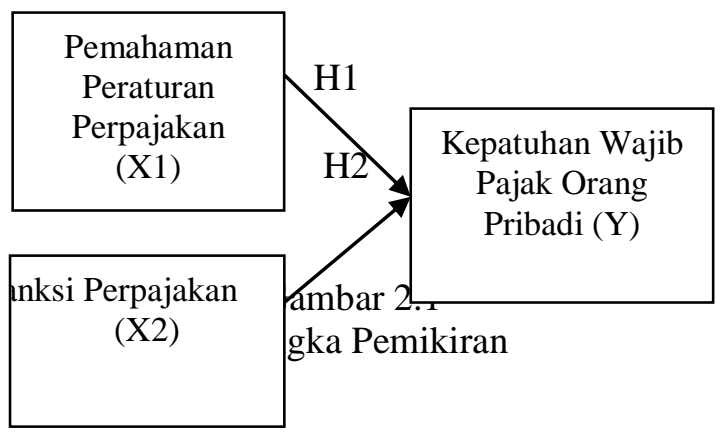

\section{METODE PENELITIAN}

\section{Jenis Penelitian}

Jenis penelitian merupakan penelitian dasar (basic research), yaitu untuk membentuk pokok pengetahuan dan memahami tentang penyelesaian masalah tertentu. Metode penelitian survei digunakan untuk mengumpulkan data yang berasal dari tempat tertentu yang alamiah (Sugiyono, 2017).

\section{Operasionalisasi Variabel}

Berikut definisi konsep variabel yang diteliti:
Tabel 4

Operasional Variabel

\begin{tabular}{|c|c|c|c|}
\hline Variabel & Indikator & $\begin{array}{c}\text { Butir } \\
\text { Pertanyaan }\end{array}$ & Skala \\
\hline $\begin{array}{l}\text { Kepatuhan } \\
\text { Wajib Pajak } \\
\text { (Y) }\end{array}$ & $\begin{array}{l}\text { 1. } \begin{array}{l}\text { Keperluan dalam } \\
\text { mendaftarkan diri ke } \\
\text { kantor pajak }\end{array} \\
\text { 2. Kepatuhan dalam } \\
\text { melaporkan SPT tepat } \\
\text { waktu } \\
\text { 3. Kepatuhan dalam } \\
\text { menghitung dan } \\
\text { membayar pajak } \\
\text { dengan benar } \\
\text { 4. } \\
\text { Kepatuhan dalam } \\
\text { membayar tunggakan }\end{array}$ & $\begin{array}{l}\text { Butir } \\
\text { Pertanyaan } \\
1,2 \\
\text { Butir } \\
\text { Pertanyaan } \\
3-5 \\
\text { Butir } \\
\text { Pertanyaan } \\
6-9 \\
\text { Butir } \\
\text { Pertanyaan } \\
\text { 10,11 }\end{array}$ & Likert \\
\hline $\begin{array}{l}\text { Pemahaman } \\
\text { Peraturan } \\
\text { Perpajakan } \\
\text { (X1) }\end{array}$ & $\begin{array}{l}\text { 1. Memahami mengenai } \\
\text { ketentuan umum dan } \\
\text { tata cara perpajakan. } \\
\text { 2. } \begin{array}{l}\text { Memahami mengenai } \\
\text { fungsi perpajakan }\end{array} \\
\text { 3. Kepatuhan dalam } \\
\text { menghitung, } \\
\text { membayar pajak } \\
\text { dengan benar }\end{array}$ & $\begin{array}{l}\text { Butir } \\
\text { Pertanyaan } \\
1,2 \\
\text { Butir } \\
\text { Pertanyaan } \\
3-5 \\
\text { Butir } \\
\text { Pertanyaan } \\
\text { 6-8 }\end{array}$ & Likert \\
\hline $\begin{array}{c}\text { Sanksi } \\
\text { Perpajakan } \\
\text { (X2) }\end{array}$ & $\begin{array}{ll}\text { 1. } & \text { Sanksi perpajakan } \\
\text { yang dikenakan bagi } \\
\text { pelanggar aturan } \\
\text { pajak cukup berat } \\
\text { 2. } \\
\text { Pengenaan sanksi } \\
\text { pajak yang cukup } \\
\text { berat merupakan } \\
\text { salah satu saran untuk } \\
\text { mendidik wajib pajak } \\
\text { 3. Sanksi pajak harus } \\
\text { dikenakan kepada } \\
\text { pelanggarnya tanpa } \\
\text { toleransi }\end{array}$ & $\begin{array}{l}\text { Butir } \\
\text { Pertanyaan } \\
1-3 \\
\text { Butir } \\
\text { Pertanyaan } \\
4,5 \\
\text { Butir } \\
\text { Pertanyaan } \\
\text { 6-8 }\end{array}$ & Likert \\
\hline
\end{tabular}

Sumber: (As'ari, 2018)

\section{Populasi dan Sampel}

Populasi dalam penelitian ini yaitu 163.372 jumlah wajib pajak pribadi yang terdaftar di KPP Pratama Cirebon Satu. Pengambilan jumlah sampel dalam penelitian ini menggunakan probability sampel dengan cara cluster sampling. Berdasarkan data dari KPP Pratama Cirebon Satu hingga Februari 2020 tercatat sebanyak 163.372 wajib pajak orang pribadi. Jumlah sampel untuk penelitian ini dengan margin of error sebesar $10 \%$ adalah:

$$
n=\frac{163.372}{1+163.372\left(0,1^{2}\right)}
$$

$n=99.9388274445$

$n=100$

Jumlah sampel dalam penelitian ini adalah sebanyak 99.9388274445 yang dibulatkan menjadi 100 wajib pajak orang pribadi. 


\section{Uji Kualitas Data}

Uji Validitas Data

Menurut (Ghazali, 2016) uji validitas digunakan untuk mengukur sah atau valid tidaknya suatu kuesioner. Pengujian validitas dapat dilakukan dengan melihat nilai correlated item atau membandingkan $\mathrm{r}$ hitung dengan $\mathrm{r}$ tabel. Total correlation dengan kriteria sebagai berikut: jika $r$ hitung > $\mathrm{r}$ table dan nilainya positif, maka semua butir pertanyaan indicator tersebut dikatakan "valid". Uji Reliabilitas Data

Menurut (Ghazali, 2016) reliabilitas sebenarnya adalah alat untuk mengukur suatu kuesioner yang merupakan indikator dari variabel atau konstruk. Suatu kuesioner dikatakan reliabel atau handal jika jawaban seseorang terhadap pertanyaan adalah konsisten atau stabil dari waktu ke waktu. Butir kuesioner dikatakan reliabel (layak) jika cronbach's alpha > dari 0,60 dan dikatakan tidak reliabel jika cronbach's alpha $<0,60$.

\section{Uji Asumsi Klasik}

\section{Uji Normalitas}

Penelitian ini menggunakan uji normalitas kolmogorov smirnov, yaitu pengujian dua sisi yang dilakukan dengan membandingkan signifikansi hasil uji ( $p$ value) dengan taraf signifikan sebesar $5 \%$.

a. Apabila signifikansi data lebih dari 5\%, maka data dapat dikatakan normal.

b. Apabila signifikansi data kurang dari 5\%, maka data dikatakan tidak normal.

\section{Uji Multikoliearitas}

Model regresi dikatakan baik jika tidak terjadi korelasi diantara variabel independen. Ada atau tidaknya multikolinearitas dapat dilihat dari nilai tolerance dan lawannya yaitu variance inflation factor (VIF). Nilai cutoff yang umum dipakai untuk menunjukan adanya multikolinearitas adalah nilai tolerance $>0,10$ atau sama dengan nilai VIF $<10$ dapat dikatakan dalam data tersebut terdapat multikolinearitas.

\section{Uji Heterooskedastisitas}

Model regresi yang baik adalah yang homokedastisitas atau yang tidak terjadi heteroskedastitas. Heteroskedastisitas dapat diuji dengan menggunakan uji Glejser. Uji Glejser adalah meregresikan antara variabel bebas dengan variabel residual absolute.

\section{Analisis Regresi Linear Berganda}

Analisis ini digunakan untuk mengetahui seberapa besar pengaruh hubungan antara variabel independen (Pemahaman peraturan perpajakan X1) dan (Sanksi perpajakan X2) terhadap variabel dependen yaitu (Kepatuhan wajib pajak Y). Model analisis regresi liniear berganda dalam penelitian ini adalah:

$$
\mathrm{KWP}=\alpha+\beta 1 \mathrm{PPP}+\beta 2 \mathrm{SP}+\mathrm{e}
$$

Keterangan:

KWP = Kepatuhan Wajib Pajak

PPP = Pemahaman Peraturan Perpajakan

SP $=$ Sanksi Perpajakan

$\alpha=$ Konstansta

$\beta 1$ dan $\beta 2=$ Koefisien regresi untuk masing-masing variabel independen

$\mathrm{e}=$ Error

\section{Uji Hipotesis \\ Uji t (Uji Parsial)}

Pengujian melalui uji $\mathrm{t}$ dilakukan dengan membandingkan t-hitung dengan t-tabel pada derajat signifikan 5\%. Apabila hasil perhitungan menunjukkan:

1. $\mathrm{t}$ hitung $>\mathrm{t}$ tabel atau apabila probabilitas kesalahan kurang dari 5\% maka $\mathrm{H0}$ ditolak dan $\mathrm{Ha}$ diterima, yang berarti bahwa variabel dependen dapat menerangkan variabel independen, dan memang ada pengaruh yang signifikan diantara kedua variabel yang diuji.

2. $\mathrm{t}$ hitung $<\mathrm{t}$ tabel atau apabila probabilitas kesalahan lebih dari 5\% maka $\mathrm{H} 0$ diterima dan $\mathrm{Ha}$ ditolak, yang berarti bahwa variabel dependen dapat menerangkan variabel independen, dan tidak ada pengaruh yang signifikan diantara kedua variabel yang diuji.

\section{Koefisien Determinasi}

Menurut (Ghazali, 2016) Koefisien Determinasi (R2) pada intinya mengukur seberapa jauh kemampuan model dalam menerangkan variasi variabel dependen. Nilai koefisien determinasi adalah antara nol dan satu. Nilai R2 yang kecil berarti kemampuan varriabel-variabel independen dalam menjelaskan variasi variabel-variabel dependen amat terbatas. Nilai yang mendekati satu berarti variabel-variabel independen memberikan hampir semua informasi yang dibutuhkan untuk memprediksi variasi variabel dependen.

\section{HASIL DAN PEMBAHASAN}

\section{Profil Responden Wajib Pajak}

Jumlah wajib pajak yang terdaftar di KPP Pratama Cirebon Satu adalah sebanyak 163.372. Peneliti membagikan kuesioner kepada wajib pajak orang pribadi yang melakukan kewajiban 
perpajakannya di KPP Pratama Cirebon Satu yang diberikan secara tidak langsung. Setelah melakukan

perhitungan hasil kuesioner, diperoleh 100 data yang dapat dianalisis.

Tabel 5

Tabulasi Kuesioner

\begin{tabular}{cccc}
\hline No. & Keterangan & $\begin{array}{c}\text { Jumlah } \\
\text { Sampel }\end{array}$ & Presentase \\
\hline 1. & Harjamukti & 17 & $17 \%$ \\
\hline 2. & Pekalipan & 11 & $11 \%$ \\
\hline 3. & Lemahwungkuk & 21 & $21 \%$ \\
\hline 4. & Kesambi & 31 & $31 \%$ \\
\hline 5. & Kejaksan & 20 & $20 \%$ \\
\hline & Total & 100 & $100 \%$ \\
\hline
\end{tabular}

Sumber: data primer diolah, 2020

Karakteristik Responden

Berdasarkan tabel 5 kecamatan kesambi dan kejaksan lebih dominan karena jumlah wajib pajak pribadi yang terdaftar di KPP Pratama Cirebon Satu lebih banyak melaksanakan kewajiban 1. Karakteristik Responden berdasarkan Jenis Kelamin

Karakteristik responden berdasarkan jenis kelamin dapat dikategorikan sebagai berikut:

perpajakannya.

\section{Tabel 6}

Jenis Kelamin Responden

\begin{tabular}{lcrr}
\hline No. & Jenis Kelamin & Jumlah & Presentase \\
\hline 1. & Pria & 55 & $55 \%$ \\
\hline 2. & Wanita & 45 & $45 \%$ \\
\hline & Total & 100 & $100 \%$ \\
\hline
\end{tabular}

Sumber: data primer diolah 2020

Berdasarkan tabel 6 menunjukan bahwa responden wajib pajak pria sebanyak $55 \%$ lebih dominan dibandingkan dengan presentase wanita yang hanya $45 \%$ karena menurut organization economic corporation and development pria cenderung lebih patuh dibanding wanita.

2. Karakteristik Responden berdasarkan Usia

Karakteristik responden berdasarkan usia dapat dikategorikan sebagai berikut:
Tabel 7

Usia Responden

\begin{tabular}{|c|c|c|c|}
\hline No. & $\begin{array}{l}\text { Usia } \\
\text { Respond } \\
\text { en }\end{array}$ & umlah & 'resentase \\
\hline 1. & -30 Tahun & 73 & $73 \%$ \\
\hline 2. & -40 Tahun & 21 & $21 \%$ \\
\hline 3. & -50 Tahun & 6 & $6 \%$ \\
\hline & & 100 & $100 \%$ \\
\hline
\end{tabular}

Sumber: data primer diolah, 2020

Berdasarkan tabel 7 menunjukan bahwa responden wajib pajak berdasarkan umur 19-30 tahun mencapai presentase $73 \%$ dan 31-40 tahun mencapai $21 \%$ karena di usia tersebut wajib pajak yang paling banyak banyak berkarir dalam bidang apapun.

3. Karakteristik berdasarkan Pendidikan Terakhir Responden

Karakteristik berdasarkan pendidikan dikategorikan sebagai berikut: 
Tabel 8

Pendidikan Terakhir Responden

\begin{tabular}{cccc}
\hline No. & Pendidikan Terakhir & Jumlah & Presentase \\
\hline 1. & Sarjana & 26 & $26 \%$ \\
\hline 2. & Diploma & 15 & $15 \%$ \\
\hline 3. & SMA/SMK & 59 & $59 \%$ \\
\hline & & 100 & $100 \%$ \\
\hline
\end{tabular}

Sumber:data primer diolah, 2020

Berdasarkan tabel 8 menunjukan bahwa tentang kewajiban perpajakannya. responden wajib pajak berdasarkan pendidikan pada tingkat pendidikan SMA/SMK lebih dominan hal ini bisa terjadi karena wajib pajak sudah memahami

4. Karakteristik Pekerja Responden

Karakteristik pada pekerjaan responden dikategorikan sebagai berikut:

Tabel 9

Pekerjaan Responden

\begin{tabular}{|c|c|c|c|}
\hline No. & Pekerjaan & Jumlah & Presentase \\
\hline 1. & Karyawan & 89 & $89 \%$ \\
\hline 2. & Non Karyawan & 11 & $11 \%$ \\
\hline & & 100 & $100 \%$ \\
\hline
\end{tabular}

\section{Sumber: data primer diolah 2020}

Berdasarkan tabel 9 menunjukan bahwa responden wajib pajak berdasarkan status pekerjaan yang paling patuh adalah karyawan dengan presetase $89 \%$ karena gaji yang sudah diterima oleh karyawan secara tidak langsung sudah terpotong PPh 21 yang dilakukan oleh perusahaan/instansi

\section{Hasil Uji Kualitas Data Uji Validitas Data}

Hasil perhitungan uji validitas variabel pemerintah. kepatuhan wajib pajak menggunakan program spss 25 for windows diperoleh sebagai berikut:

Tabel 10

Hasil Uji Validitas Data

\begin{tabular}{|c|l|r|r|c|}
\hline \multirow{4}{*}{ VARIABEL } & $\begin{array}{c}\text { Butir } \\
\text { Pertan } \\
\text { yaan }\end{array}$ & hitung & tabel & eterangan \\
\hline & Y.P1 & 0,478 & 0,195 & Valid \\
\cline { 2 - 5 } & Y.P2 & 0,485 & 0,195 & Valid \\
\cline { 2 - 5 } & Y. P3 & 0,529 & 0,195 & Valid \\
\cline { 2 - 5 } & Y.P4 & 0,442 & 0,195 & Valid \\
\cline { 2 - 5 } Kepatuhan & Y.P5 & 0,543 & 0,195 & Valid \\
\cline { 2 - 5 } $\begin{array}{c}\text { Wajib } \\
\text { Pajak (Y) }\end{array}$ & Y.P6 & 0,629 & 0,195 & Valid \\
\cline { 2 - 5 } & Y.P7 & 0,618 & 0,195 & Valid \\
\cline { 2 - 5 } & Y.P8 & 0,515 & 0,195 & Valid \\
\cline { 2 - 5 } & Y.P9 & 0,473 & 0,195 & Valid \\
\cline { 2 - 5 } & Y.P10 & 0,567 & 0,195 & Valid \\
\cline { 2 - 5 } & Y.P11 & 0,483 & 0,195 & Valid \\
\hline \multirow{4}{*}{$\begin{array}{c}\text { P1.P1 } \\
\text { Peraturan }\end{array}$} & 0,528 & 0,195 & Valid \\
\cline { 2 - 5 } Perpajakan \\
\cline { 2 - 5 } (X1) & X1.P2 & 0,685 & 0,195 & Valid \\
\cline { 2 - 5 } & X1.P4 & 0,476 & 0,195 & Valid \\
\cline { 2 - 5 } & X1.P5 & 0,470 & 0,195 & Valid \\
\cline { 2 - 5 } & X1.P6 & 0,712 & 0,195 & Valid \\
\cline { 2 - 5 } & X1.P7 & 0,701 & 0,195 & Valid \\
\hline
\end{tabular}




\begin{tabular}{|c|l|r|r|c|}
\hline & X1.P8 & 0,575 & 0,195 & Valid \\
\hline \multirow{4}{*}{$\begin{array}{c}\text { Sanksi } \\
\text { Perpajakan } \\
(X 2)\end{array}$} & X2.P1 & 0,489 & 0,195 & Valid \\
\cline { 2 - 5 } & X2.P2 & 0,573 & 0,195 & Valid \\
\cline { 2 - 5 } & X2.P3 & 0,626 & 0,195 & Valid \\
\cline { 2 - 5 } & X2.P4 & 0,690 & 0,195 & Valid \\
\cline { 2 - 5 } & X3.P5 & 0,433 & 0,195 & Valid \\
\cline { 2 - 5 } & X4.P6 & 0,662 & 0,195 & Valid \\
\cline { 2 - 5 } & X2.P7 & 0,735 & 0,195 & Valid \\
\cline { 2 - 5 } & X2.P8 & 0,675 & 0,195 & Valid \\
\hline
\end{tabular}

Sumber: Data primer diolah dari SPSS, 2020

Berdasarkan tabel diatas dapat dilihat nilai $\mathrm{r}$ Pemahaman Peraturan Perpajakan, dan Sanksi hitung Corrected item Total correlation untuk Perpajakan adalah valid dan layak untuk dilakukan indikator Variabel Kepatuhan Wajib Pajak, pengujian untuk tahap berikutnya.

Pemahaman Peraturan Perpajakan, dan Sanksi Uji Reliabilitas Data

Perpajakan $\mathrm{r}$ hitung $>$ dari pada $\mathrm{r}$ tabel 0,195 .

Sehingga dapat diambil kesimpulan bahwa kepatuhan wajib pajak menggunakan program spss semua indikator variaebel Kepatuhan Wajib Pajak, 25 for windows diperoleh sebagai berikut:

\section{Tabel 11}

Hasil Uji Reliabilitas Data

\begin{tabular}{|c|cl|}
\hline VARIABEL & Cronbranch's alpha & eterangan \\
\hline Kepatuhan Wajib Pajak & 0,726 & Reliabel \\
\hline emahaman Peraturan Perpajakan & 0,747 & Reliabel \\
\hline Sanksi Perpajakan & 0,750 & Reliabel \\
\hline
\end{tabular}

Sumber: Data primer diolah, 2020

Berdasarkan tabel 11 menunjukan bahwa nilai cronbranch's alpha > 0,60 di setiap variabel hal ini menunjukan seluruh variabel adalah reliable dan konsisten dari waktu ke waktu.

\section{Uji Asumsi Klasik \\ Uji Normalitas}

Berikut hasil uji normalitas.

Tabel 12

Uji Kolomogorov-Smirnov

\section{One-Sample Kolmogorov-Smirnov Test}

\begin{tabular}{llr} 
& & \multicolumn{1}{c}{$\begin{array}{c}\text { Unstandardized } \\
\text { Residual }\end{array}$} \\
\hline $\mathrm{N}$ & & 100 \\
\hline Normal & Mean & .0000000 \\
\cline { 2 - 3 } Parameters ${ }^{\mathrm{a}, \mathrm{b}}$ & $\begin{array}{l}\text { Std. } \\
\text { Deviation }\end{array}$ & 2.70823722 \\
\hline \multicolumn{1}{c}{$\begin{array}{l}\text { Most Extreme } \\
\text { Differences }\end{array}$} & Absolute & .055 \\
\cline { 2 - 3 } & Positive & .055 \\
\cline { 2 - 3 } & Negative & -.042 \\
\hline Test Statistic & & .055 \\
\hline Asymp. Sig. (2-tailed) & $.200^{\mathrm{c}, \mathrm{d}}$ \\
\hline
\end{tabular}
a. Test distribution is Normal.
b. Calculated from data.
c. Lilliefors Significance Correction.
$\mathrm{d}$. This is a lower bound of the true

Sumber: $D a_{i}$ significance. 
Berdasarkan hasil tabel di atas diperoleh nilai Kolmogorov-Smirnov sebesar 0,055 dengan Asymp.Sig.(2-tailed) sebesar 0,200. Karena nilai

Berikut adalah hasil dari uji multikolinearitas: signifikan yang diperoleh 0,200 lebih besar dari nilai signifikan yang diharapkan yaitu 0,05 . Hal tersebut berarti bahwa residual untuk semua variabel dalam penelitian ini berdistribusi normal.

Tabel 13

Hasil Uji Multikoleniaritas

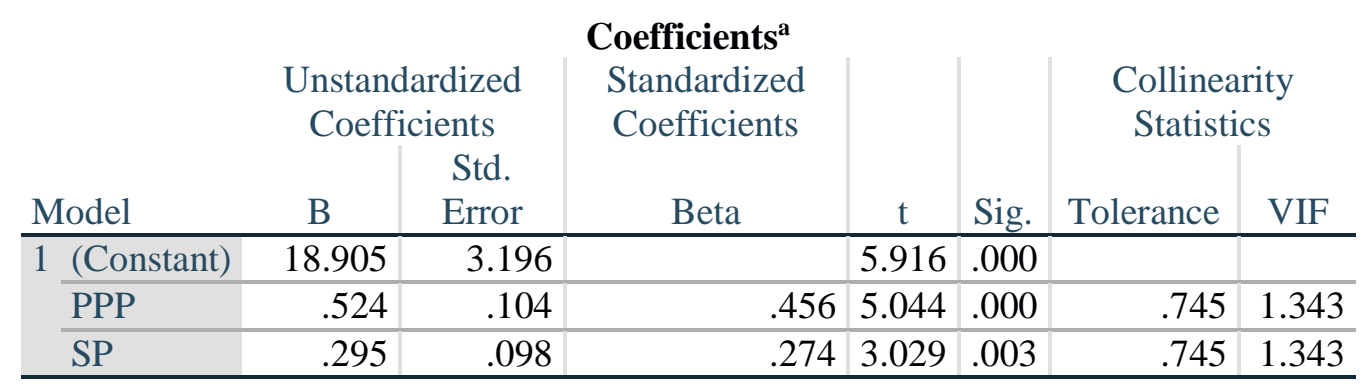

a. Dependent Variable: Kepatuhan Wajib Pajak

Sumber: Data primer diolah, 2020

Berdasarkan tabel 13 menunjukkan bahwa nilai tolerance untuk variabel pemahaman peraturan perpajakan adalah sebesar 0,745 yang lebih besar dari 0,10 dan nilai VIF sebesar 1,343 yang lebih kecil dari 10. Untuk variabel sanksi perpajakan nilai tolerance menunjukkan nilai adalah sebesar 0,745 yang lebih besar dari 0,10 dan nilai VIF sebesar

\section{Uji Heteroskedastisitas}

Berikut adalah hasil uji glejser:
1,343 yang lebih kecil dari 10. Berdasarkan hasil dari nilai tolerance dan VIF dapat disimpulkan bahwa dalam model regresi tidak terdapat multikolinearitas antar variabel independen dan dapat digunakan untuk memprediksi kepatuhan wajib pajak orang pribadi di KPP Pratama Cirebon Satu.

\begin{tabular}{|c|c|c|c|c|c|}
\hline \multirow[b]{3}{*}{ Model } & \multicolumn{3}{|c|}{$\begin{array}{c}\text { Tabel 14 } \\
\text { Hasil Uji Heteroskedatisitas } \\
\text { Coefficients }^{\mathrm{a}}\end{array}$} & \multirow[b]{3}{*}{$\mathrm{t}$} & \multirow[b]{3}{*}{ Sig } \\
\hline & \multicolumn{2}{|c|}{ Unstandardized Coefficients } & \multirow{2}{*}{$\begin{array}{c}\text { Standardized Coefficients } \\
\text { Beta }\end{array}$} & & \\
\hline & $\mathrm{B}$ & Std. Error & & & \\
\hline 1 (Constant) & 2.140 & 1.837 & & 1.165 & .247 \\
\hline $\mathrm{PPP}_{-}$ & -.006 & .060 & -.012 & -.100 & .920 \\
\hline $\mathrm{SP}_{-}$ & .008 & .056 & .017 & .141 & .888 \\
\hline
\end{tabular}

a. Dependent Variable: Abs_RES

Sumber: Data primer diolah, 2020

0,888 .

Maka

Berdasarkan hasil pengujian pada tabel di atas menunjukkan bahwa nilai signifikan dari setiap variabel independen lebih besar dari 0,05. Nilai signifikan untuk variabel pemahaman peraturan perpajakan adalah sebesar 0,920 . Nilai signifikan untuk variabel sanksi perpajakan adalah sebesar dapat disimpulkan bahwa model regresi dalam penelitian ini tidak mengandung adanya heteroskedastisitas, sehingga model regresi layak untuk memprediksi penerapan pemahaman peraturan perpajakan dan sanksi perpajakan terhadap kepatuhan wajib pajak orang pribadi. 


\section{Analisis Regresi Linear Berganda}

Berikut dapat disajikan hasil pengolahan tabel 15 adalah sebagai berikut: data dengan analisis regresi linear berganda pada

Tabel 4.15

Hasil Uji Regresi Linear Berganda

Coefficients $^{\mathrm{a}}$

Unstandardized Standardized Coefficients Coefficients

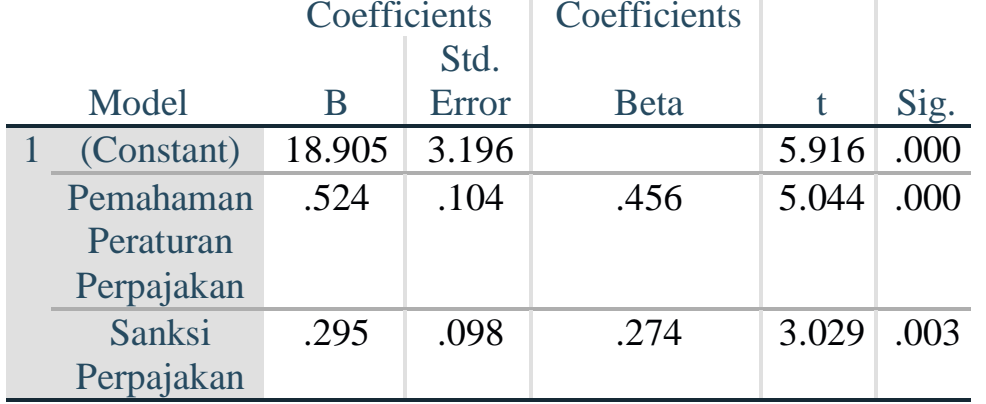

a. Dependent Variable: Kepatuhan Wajib Pajak

Sumber: Data primer diolah, 2020

Berdasarkan hasil analisis regresi berganda yang kepatuhan wajib pajak.

disajikan pada tabel di atas, maka diperoleh 2. Pengujian Sanksi Perpajakan terhadap Kepatuhan persamaan regresi linear sebagai berikut:

$\mathrm{KWP}=24.018+0,343 \mathrm{PPP}+0,295 \mathrm{SP}+\mathrm{e}$ Wajib Pajak

Berdasarkan tabel 16 dapat disimpulkan bahwa

Uji Hipotesis

Uji t (Uji Parsial)

Tabel 16

Hasil Uji Parsial (Uji t)

Unstandardized Standardized Coefficients Coefficients variabel sanksi perpajakan memiliki nilai signifikansi sebesar $0,003<0,05$ dan nilai t-hitung $>$ t-tabel yaitu $3.029>1,660$, maka $\mathrm{H} 0$ dapat ditolak dan H1 diterima, artinya bahwa sanksi perpajakan berpengaruh terhadap kepatuhan wajib pajak.

\section{Uji Koefesien Determinasi (R2)}

Uji koefisien determinasi digunakan untuk mengukur seberapa jauh kemampuan model untuk

\begin{tabular}{|c|c|c|c|c|c|}
\hline Model & B & $\begin{array}{c}\text { Std. } \\
\text { Error }\end{array}$ & Beta & $\mathrm{t}$ & $\begin{array}{l}\text { menguk } \\
\text { meingran }\end{array}$ \\
\hline 1 (Constant) & 18.905 & 3.196 & & 5.916 & 5 kedoro \\
\hline $\begin{array}{l}\text { Pemahaman } \\
\text { Peraturan } \\
\text { Perpajakan }\end{array}$ & .524 & .104 & .456 & 5.044 & $\begin{array}{l}4 \text { indep } \\
\text { sanga } \\
\text { deter }\end{array}$ \\
\hline $\begin{array}{l}\text { Sanksi } \\
\text { Perpajakan }\end{array}$ & .295 & .098 & .274 & 3.029 & bẹvidgut: \\
\hline
\end{tabular}

a. Dependent Variable: Kepatuhan Wajib Pajak

Berikut kesimpulan dari hasil uji parsial (uji t) sebagai berikut:

1. Pengujian Pengaruh Pemahaman Peraturan Perpajakan terhadap Kepatuhan Wajib Pajak

Berdasarkan tabel 16 dapat disimpulkan bahwa variabel pemahaman pearturan perpajakan memiliki nilai signifikansi sebesar $0,000<0,05$ dan nilai thitung > t-tabel yaitu 5.044 >1,660, maka H0 dapat ditolak dan Ha diterima, artinya bahwa pemahaman peraturan perapajakan berpengaruh terhadap

\begin{tabular}{lc|r|r|r} 
& & \multicolumn{2}{c}{ Model Summary } \\
Model & $\mathrm{R}$ & Square & $\begin{array}{c}\text { Adjusted R } \\
\text { Square }\end{array}$ & $\begin{array}{c}\text { Std. Error of } \\
\text { the Estimate }\end{array}$ \\
\hline 1 & $.640^{\mathrm{a}}$ & .409 & .397 & 2.736 \\
\hline
\end{tabular}

a. Predictors: (Constant), Sanksi Perpajakan, Pemahaman Peraturan Perpajakan

Sumber: Data primer diolah, 2020

Berdasarkan tabel 17 menunjukan bahwa nilai $\mathrm{R}$ Square sebesar 0,409 atau 40,9\%. Artinya kemampuan variabel independen pada penelitian ini 
yaitu Pemahaman Peraturan Perpajakan dan Sanksi Perpajakan dalam menjelaskan variasi variabel Kepatuhan Wajib Pajak sebesar 40,9\% dan sisanya yaitu sebesar 59,1\% (100\% - 40,9\%) dijelaskan oleh variabel lain.

\section{Pembahasan}

\section{Pengaruh Pemahaman Peraturan Perpajakan terhadap Kepatuhan Wajib Pajak}

Berdasarkan hasil penelitian dapat diketahui bahwa berdasarkan hasil uji hipotesis yang menyatakan bahwa terdapat pengaruh dari pemahaman peraturan perpajakan terhadap kepatuhan wajib pajak dengan tingkat signifikan sebesar $0,000<0,05$.

Hasil penelitian ini sejalan dengan penelitian yang dilakukan oleh, (Priambodo \& Yushita, 2017), (Efriyenty, 2017), (Kusuma, 2017), (Bahri, Diantimala, \& Majid, 2018), dan (As'ari, 2018) yang meneliti tentang pemahaman peraturan perpajakan menyatakan bahwa pemahaman peraturan perpajakan berpengaruh terhadap kepatuhan wajib pajak. Sedangkan penelitian sebelumnya yang dilakukan oleh (Saragih \& S, 2017)yang menyatakan bahwa pemahaman peraturan perpajakan tidak berpengaruh terhadap kepatuhan wajib pajak.

Jika dilihat pada hasil pengelolahan distribusi frekuensi variabel pemahaman peraturan perpajakan diketahui bahwa hasil setiap indikator pertanyaanpertanyaan yang terdiri dari; memahami mengenai ketentuan umum dan tata cara perpajakan, memahami mengenai fungsi perpajakan, dan kepatuhan dalam menghitung dan membayar pajak dengan benar. Mayoritas wajib pajak menjawab pada kategori "setuju", hal ini menunjukan ketika seorang wajib pajak semakin memahami tentang peraturan perpajakan yang berlaku di Indonesia terutama untuk wilayah KPP Pratama Cirebon Satu maka akan meningkatkan kepatuhan wajib pajak di KPP Pratama Cirebon Satu.

Berdasarkan indikator pertanyaan-pertanyaan tersebut menjelaskan bahwa pemahaman peraturan perpajakan sudah banyak dipatuhi oleh wajib pajak yang telah memenuhi kewajiban perpajakannya dikatakan baik, walaupun ada beberapa wajib pajak yang belum memahami peraturan perpajakan dalam memenuhi kewajiban perpajakannya.

Adapun teori atribusi yang dijelaskan oleh (Robbins \& Jugde, 2017) teori atribusi adalah teori yang menjelaskan bahwa ketika individu mengamati sikap seorang, individu tersebut berupaya untuk menentukan apakah sikap tersebut disebabkan secara internal atau eksternal. Sikap yang disebabkan secara internal merupakan sikap yang diyakini berada di bawah kendali pribadi seorang individu, dengan kata lain tidak terpengaruh oleh hal lain. Sikap yang disebabkan secara eksternal merupakan sikap yang dianggap sebagai akibat dari sebab-sebab luar yaitu individu tersebut dianggap telah dipaksa berperilaku demikian oleh situasi. Dalam hal ini faktor internal yang timbul dari wajib pajak yaitu pemahaman peraturan perpajakan yaitu memahami secara baik dan benar terkait ketentuan dan peraturan-peraturan perpajakan, wajib pajak yang memahi peraturan perpajakan secara baik dan betul-betul memahami peraturan perpajakan akan melakukan kewajiban perpajakan dalam melapor dan membayarkan pajaknya, hal ini akan meningkatkan jumlah wajib pajak yang sudah melapor dan membayarnya. Factor eksternal yang timbul dari pemahaman peraturan perpajakan yaitu ketika wajib pajak melakukan mempelajari, membaca dan mengerti terkait pemahaman tentang peraturan perpajakan, hal ini akan memudahkan wajib pajak serta dapat meningkatkan kepatuhan wajib pajaknya.

\section{Pengaruh Sanksi Perpajakan terhadap Kepatuhan Wajib Pajak}

Berdasarkan hasil penelitian dapat diketahui bahwa berdasarkan hasil uji hipotesis yang menyatakan bahwa terdapat pengaruh dari pemahaman peraturan perpajakan terhadap kepatuhan wajib pajak dengan tingkat signifikan sebesar $0,003<0,05$.

Hasil penelitian lainnya dilakukan oleh (Ngadiman \& Huslin, 2016), (Ariesta \& Latifah, 2017), (Alfiyah \& Latifah, 2017), (Tene, Sondakh, \& Warongan, 2017), (I. P. E. Adiputra \& Wirama, 2017), (Brata, Yuningsih, \& Kesuma, 2017), (Saragih \& S, 2017), dan (Agustini \& Widhiyani, 2019) yang meneliti tentang sanksi perpajakan menyatakan bahwa sanksi perpajakan berpengaruh terhadap kepatuhan wajib pajak. Sedangkan penelitian yang dilakukan oleh (Bahri et al., 2018) dan (Putri \& Agustin, 2018) yang menyatakan bahwa sanksi perpajakan tidak berpengaruh terhadap kepatuhan wajib pajak.

Jika dilihat pada hasil pengelolaan distribusi frekuensi variabel sanksi perpajakan diketahui bahwa hasil setiap indikator pertanyaan-pertanyaan yang terdiri dari; sanksi perpajakan yang dikenakan bagi pelanggar aturan pajak cukup berat, 
penggenaan sanksi pajak yang cukup berat merupakan salah satu saran untuk mendidik wajib pajak, dan sanksi pajak harus dikenakan kepada pelanggarnya tanpa toleransi. Mayoritas jawaban responden menjawab pada kategori "setuju", hal ini menunjukan ketika seorang wajib pajak semakin disiplin dalam memenuhi kewajiban perpajakannya, serta KPP Pratama Cirebon Satu yang terus meningkatkan sanksi perpajakannya sehingga kepatuhan wajib pajak di KPP Pratama Cirebon Satu dapat meningkat.

Berdasarkan indikator pertanyaan-pertanyaan tersebut menjelaskan bahwa sanksi perpajakan sudah banyak dipatuhi oleh wajib pajak yang telah memenuhi kewajiban perpajakan dikatakan baik, walaupun ada beberapa wajib pajak yang belum memahami sanksi perpajakan dalam memenuhi kewajiban perpajakannya.

Adapun teori atribusi yang dijelaskan oleh (Robbins \& Jugde, 2017) teori atribusi adalah teori yang menjelaskan bahwa ketika individu mengamati sikap seorang, individu tersebut berupaya untuk menentukan apakah sikap tersebut disebabkan secara internal atau eksternal. Sikap yang disebabkan secara internal merupakan perilaku yang diyakini berada di bawah kendali pribadi seorang individu, dengan kata lain tidak terpengaruh oleh hal lain. Sikap yang disebabkan secara eksternal merupakan perilaku yang dianggap sebagai akibat dari sebab-sebab luar yaitu individu tersebut dianggap telah dipaksa berperilaku demikian oleh situasi. Dalam hal ini faktor eksternal yang timbul dari wajib pajak yaitu sanksi perpajakan dengan mematuhi sanksi administrasi dan sanksi pidana yang sesuai dengan peraturan-peraturan perpajakan yang berlaku untuk wajib pajak maka wajib pajak harus melakukan kewajiban perpajakan dengan baik hal ini akan meningkatkan jumlah wajib pajak yang sudah membayar dan melaporkan pajaknya. Faktor eksternal yang timbul dari wajib pajak yaitu ketika wajib pajak merasa tertekan apabila wajib pajak tidak melakukan kewajiban perpajakan kemudian tindakan wajib pajak dalam membayar dan melaporkan pajaknya akan mempermudah wajib pajak sehingga tingkat kepatuhan wajib pajak semakin meningkat.

\section{KESIMPULAN DAN SARAN}

\section{Kesimpulan}

Berdasarkan hasil penelitian serta pembahasan pada bah 4 terkait pengaruh pemahaman peraturan perpajakan dan sanksi perpajakan terhadap kepatuhan wajib pajak maka dapat disimpulkan bahwa:

1. Pemahaman peraturan perpajakan berpengaruh terhadap kepatuhan wajib pajak, hal ini dikarenakan banyak wajib pajak yang sudah memahami terkait ketentuan dan peraturan-peraturan perpajakan sehingga dapat meningkatkan kepatuhan wajib pajak.

2. Sanksi perpajakan berpengaruh terhadap kepatuhan wajib pajak, hal ini dikarenakan sanksi perpajakan sudah banyak dipatuhi oleh wajib pajak yang telah memenuhi kewajiban perpajakannya sehingga dapat meningkatkan kepatuhan wajib pajak.

\section{Implikasi \\ Implikasi Teoritis}

\section{Bagi Akademisi}

Hasil penelitian ini diharapkan dapat menambah ilmu pengetahuan dan wawasan mengenai faktorfaktor yang mempengaruhi kepatuhan wajib pajak orang pribadi pada Kantor Pelayanan Pajak Pratama Cirebon Satu, khususnya factor pemahaman peraturan perpajakan dan sanksi perpajakan.

Bagi Peneliti Lainnya

Hasil penelitian ini diharapkan dapat dijadikan sebagai bahan referensi bagi penelitian selanjutnya yang berkaitan dengan analisis faktor-faktor yang mempengaruhi kepatuhan wajib pajak orang pribadi di Kantor Pelayanan Pajak Pratama Cirebon Satu, khususnya faktor pemahaman peraturan perpajakan dan sanksi perpajakan.

\section{Implikasi Praktis}

Kantor Pelayanan Pajak Pratama Cirebon Satu harus terus meningkatkan kualitas pelayanan pajak, sehingga bisa mendorong wajib pajak untuk patuh dalam melaksanakan kewajiban perpajakannya. Hasil penelitian ini dapat digunakan sebagai bahan pertimbangan informasi bagi pemerintah untuk mengkaji lebih dalam mengenai Kepatuhan WPOP yang dilakukan oleh wajib pajak di kantor-kantor pelayanan pajak di Indonesia khususnya di KPP Pratama Cirebon Satu agar dapat meningkatkan upaya pemerintah dalam menangani wajib pajak yang kurang taat dan patuh dalam pembayaran dan pelaporan pajak. Selain itu penelitian ini dapat digunakan sebagai salah satu referensi dalam menetapkan kebijakan dalam bidang perpajakan.

\section{Keterbatasan}

Peneliti menyadari bahwa penelitian ini masih terdapat beberapa kekurangan dan kelemahan yang 
disebabkan oleh beberapa faktor yaitu:

1. Berdasarkan hasil R Square (R2) sebesar 0,409 dapat disimpulkan bahwa pemahaman peraturan perpajakan dan sanksi perpajakan berpengaruh terhadap kepatuhan wajib pajak sebesar 40,9\%. Sedangkan sisanya yaitu sebesar $59,1 \%$ dipengaruhi oleh variabel lain yang tidak diteliti.

2. Adanya wabah covid-19 peneliti tidak bisa memberikan kuesioner secara langsung, dan seta sekunder yang tidak bisa di dapat dengan tepat waktu.

3. Akibat dari keterbatasan berbagai faktor tersebut maka penelitian ini masih banyak kekurangan, untuk itu peneliti dengan senang hati menerima kritik dan saran yang bersifat membangun demi kesempurnaan penelitian ini.

\section{Saran}

Berdasarkan keterbatasan yang telah dijelaskan sebelumnya terkait penelitian ini, maka peneliti memberikan saran kepada peneliti-peneliti berikutnya, yaitu:

1. Diharapkan kepada aparat pajak harus terus meningkatkan kualitas pelayanan pajak, sehingga bisa mendorong wajib pajak untuk patuh dalam melaksanakan kewajiban perpajakannya. Pemahaman wajib pajak tentang peraturan perpajakan tentang tarif pajak dan ketentuanketentuan perpajakan yang berlaku pada Indonesia dirasa masih kurang dipahami oleh wajib pajak, sebagai akibatnya perlu adanya pengenalan karena sebagian wajib pajak belum memahami peraturan perpajakan. Sanksi perpajakan pula harus ditingkatkan untuk disosialisasikan dengan baik kepada wajib pajak agar wajib pajak dapat memahami hal-hal yang berkaitan dalam pelaksanaan sanksi perpajakan dan penyebabpenyebab dikenakannya suatu sanksi perpajakan untuk wajib pajak.

2. Kepada wajib pajak diharapkan dapat lebih meningkatkan kepatuhannya dalam memenuhi kewajiban pajaknya, menaikkan pengetahuan dan pemahaman terhadap peraturan perpajakan, sebagai akibatnya wajib pajak dapat jujur dalam melaporkan pajaknya.

3. Bagi peneliti selanjutnya, diharapkan peneliti selanjutnya dapat menemui responden secara langsung.

\section{DAFTAR PUSTAKA}

Adiputra, I. P. E., \& Wirama, D. G. (2017). PENGARUH KUALITAS PELAYANAN, SANKSI PERPAJAKAN DAN KESADARAN WAJIB PAJAK PADA KEPATUHAN WAJIB PAJAK. E-Jurnal Akuntansi Universitas Udayana, 18(1), 588-615.

Agustini, K. D., \& Widhiyani, N. L. S. (2019). Pengaruh Penerapan E-Filing, Sosialisasi Perpajakan, Sanksi Perpajakan Terhadap Kepatuhan Wajib Pajak Orang Pribadi. E-Jurnal Akuntansi Universitas Udayana, 27(2), 1343-1364. https://doi.org/10.24843/eja.2019.v27.i02.p19

Alfiyah, N., \& Latifah, S. W. (2017). Pengaruh Pelaksanaan Kebijakan Sunset Policy, Tax Amnesty, Dan Sanksi Pajak Terhadap Kepatuhan Wajib Pajak Orang Pribadi. Jurnal Reviu Akuntansi Dan Keuangan, 7(2), 1081-1090. https://doi.org/10.22219/jrak.v7i2.21

Ariesta, R. P., \& Latifah, L. (2017). Pengaruh Kesadaran Wajib Pajak , Sanksi Perpajakan , Sistem Administrasi Perpajakan Modern, Pengetahuan Korupsi , dan Tax Amnesty Terhadap Kepatuhan Wajib Pajak di KPP Pratama Semarang. Accounting Anallysiss Journal, 1(2), 173-187.

As'ari, N. G. (2018). Pengaruh Pemahaman Peraturan Perpajakan, Kualitas Pelayanan, Kesadaran Wajib Pajak dan Sanksi Perpajakan terhadap Kepatuhan Wajib Pajak Orang Pribadi. 16(6), 64-76.

Bahri, S., Diantimala, Y., \& Majid, M. S. A. (2018). Pengaruh Kualitas Pelayanan Pajak, Pemahaman Peraturan Perpajakan serta Sanksi Perpajakan terhadap Kepatuhan Wajib Pajak (Pada Kantor Pajak KPP Pratama Kota Banda Aceh). Jurnal Prespektif Ekonomi Darussalam, 4(September), 318-334.

Brata, J. D., Yuningsih, I., \& Kesuma, A. I. (2017). Pengaruh Kesadaran Wajib Pajak, Pelayanan Fiskus, dan Sanksi Pajak terhadap Kepatuhan Wajib Pajak Orang Pribadi yang Melakukan Kegiatan Usaha dan Pekerjaan Bebas di Kota Samarinda. Forum Ekonomi, 19(1), 69-81.

Efriyenty, D. (2017). PENGARUH KUALITASPELAYANAN PAJAK, PEMAHAMAN PERATURAN PERPAJAKAN SERTA SANKSI PERPAJAKAN TERHADAP KEPATUHAN WAJIB PAJAK ORANG PRIBADI YANG TERDAFTAR DI KANTOR PELAYANAN PAJAK PRATAMA KOTA BATAM. Jurnal AKSARA PUBLIC, 1(4), 49-62.

Kusuma, K. C. (2017). PENGARUH KUALITAS PELAYANAN PAJAK, PEMAHAMAN PERATURAN PERPAJAKAN SERTA SANKSI PERPAJAKAN TERHADAP KEPATUHAN WPOP. Jurnal Profita Edisi $3,1-14$.

Ngadiman, N., \& Huslin, D. (2016). Pengaruh Sunset Policy, Tax Amnesty, dan Sanksi pajak terhadap Kepatuhan Wajib Pajak (Studi Empiris di Kantor Pelayanan Pajak Pratama Jakarta Kembangan). Jurnal Akuntansi, XIX(02), 1-522. https://doi.org/10.4018/978-1-5225-0651-5

Nirawan, A. (2013). Pengaruh Pemahaman Peraturan Perpajakan Terhadap Kepatuhan Wajib Pajak Dengan Preferensi Risiko Sebagai Variabel Moderating. Accounting Analysis Journal, 2(3), 1-9.

Pohan, C. A. (2016). Pedoman Lengkap Pajak Pertambahan Nilai; Teori, Konsep dan Aplikasi PPN. Gramedia Pustaka Utama. 
Priambodo, P., \& Yushita, A. N. (2017). Pengaruh Pemahaman Peraturan Perpajakan, Sanksi Perpajakan dan Kesadaran Wajib Pajak terhadap Kepatuhan Wajib Pajak Orang Pribadi di Kantor Pelayanan Pajak Pratama Kabupaten Purwrejo Tahun 2017. Jurnal Profita Edisi 5 Tahun 2017 Awareness, 2, 1-16.

Putri, N. E., \& Agustin, D. (2018). Pengaruh Pengertahuan Perpajakan dan Sanksi Perpajakan terhadap Kepatuhan Wajib Pajak Pribadi (Studi Kasus: KPP Pratama Kebayoran Lama Kota Jakarta Selatan). Fakultas Ekonomi Dan Bisnis, 3(2), 1-9.

Robbins, S. P., \& Jugde, T. A. (2017). Perilaku Organisasi (P. P. Lestari (ed.); 5th ed.). Salemba Empat.

Saragih, F., \& S, D. (2017). PENGARUH KESADARAN WAJIB PAJAK, PEMAHAMAN PERATURAN PERPAJAKAN DAN SANKSI PAJAK TERHADAP KEPATUHAN WAJIB PAJAK ORANG PRIBADI (PADA KPP PRATAMA MEDAN KOTA). Jurnal Manajemen Perpajakan, 6(1), 1-130.

Tene, J. H., Sondakh, J. J., \& Warongan, J. D. L. (2017). PENGARUH PEMAHAMAN WAJIB PAJAK, KESADARAN PAJAK, SANKSI PERPAJAKAN DAN PELAYANAN FISKUS TERHADAP 11 ' WAJIB PAJAK ORANG PRIBADI YANG TERDAFTAR DI KPP PRATAMA MANADO). Jurnal Akuntansi, 3(1), 443-453. https://doi.org/10.24964/ja.v3i1.43 